\title{
建築ヴォリュームの配列による交差点の空間構成 現代日本の都市空間における空地の構成形式に関する研究 (4) \\ SPATIAL COMPOSITION OF INTERSECTIONS BY ARRANGEMENT OF BUILDING VOLUMES
}

A study on spatial composition of contemporary urban vacant land (4)

\section{安森亮雄*, 斎藤啓佑 ${ }^{* *}$, 坂本一成 ${ }^{* * *}$, 寺内 美紀子**** \\ Akio YASUMORI, Keisuke SAITO, Kazunari SAKAMOTO and Mikiko TERAUCHI}

The aim of this paper is to clarify characteristics of intersections in the center district of Tokyo in terms of spatial compositions with surroundings. Initially, the configurations of intersections are analyzed through the street patterns, nearby infrastructures such as rivers or elevated traffics, and its topography. Secondly, the building volumes are analyzed as a combination of building rows with features of the corner lots.

Finally, 9 spatial types are clarified based on 3 characteristics: axis by street patterns and nearby infrastructures, centrality by buildings at the corner lots, and boundary by arrangement of buildings.

Keywords: intersection, vacant land, building volume, street, spatial composition 交差点, 空地, 建築ヴオリューム, 街路, 構成形式

1. 序

\section{1 都市中心部における交差点の空間}

交差点は街路の結節点として交通の要所であるだけではなく、街 路沿いに建物が建ち並ぶことで、都市中心部の街並みが複合された 特徴的な場所となっている。こうした交差点は古くから「辻」や「街 角」と呼ばれ、角地に人目を引く建物が建つなど地理的に重要な場 所となってきた注1)。また日本の都市空間では街路は地形に応じて 様々な形をなし、幹線街路に沿って路線商業地が形成されるなじ、 街路に沿った特徴的な建物の配列がみられる。こうしたことから交 差点は、十字路や三叉路といった街路の交差の形状、建物や道路高 架などの構築物の配列、交差点一帯の地形などによって特徵的な空 間となっており、例えば銀座数寄屋橋交差点や渋谷八チ公口スクラ ンブル交差点などのように、地域を代表する重要な場所となってい るものと考えられる。これまで筆者らは、このような街路空間を含 む都市の空地を、周囲の構築物との相対的な関係により成立する空 間と捉え、その構成形式について研究を進めてきた。既報 ${ }^{2,3,4)}$ では、 駅前広場などの建物に囲まれた空地を対象として、建物や交通高架 といった立体的なヴォリューム（以下、建築ヴォリューム）の配列 の形式を明らかにし、街路や堀割等の開放部による囲夕の外部への 連続にもとづく構成的な特徵を見いだした。本研究では、これまで
に検討した建物に囲まれた空地に対して、街路が交わる交差点を対 象とすることにより、多方向に広がる空間の連続性にもとづく空地 の構成形式を明らかにするものである。このことは、交差点を中心 に街路空間の複合を位置づける試みでもあり、構築物の配列を通し て都市空間の構成的な性格の一端を明らかにする試みとして有意義 なものと思われる。

\section{2 本研究の方法と目的}

交差点は複数の街路が接続する空間であり、前述したように街路 の形状や、街路に沿って建ち並ぶ建物、交差点一帯の地形などによ り特徴づけられている。本研究では、こうした特徴がみられる交差 点として、主要な幹線街路が高密度に発達し、多様な建物や地形 がみられる東京都心 5 区の幹線街路の交差点を資料とし（表 1 , 全 132 資料)、交差点の空間を交差点に接続する街路を含めて捉えて いる注2)。ここで三叉路や四叉路といった交差点の形状は、周囲の 地形や河川、道路高架などの都市の基盤をな寸要素と密接な関わり をもつと考えられ、それに対して、街路に沿って建ち並ぶ建物の集 合は交差点の空間を立体的に限定していると捉えることができる （図 1)。これらのことを踏まえて本研究では、まず 2 章において交 差点の形状と、地形や河川、道路や鉄道等の高架（以下、交通高架） の組合せを検討する。続く 3 章において、交差点に面する建物を街

\footnotetext{
* 宇都宮大学大学院 准教授 ·博士 (工学)

** 東京工業大学大学院 修士課程

*** 東京工業大学 名誉教授・工博

$* * * *$ 茨城大学工学部 准教授. 博士 (工学)
}

Assoc. Prof., Graduate School, Utsunomiya University, Dr. Eng.

Graduate Student, Graduate School, Tokyo Institute of Technology

Emeritus Prof., Tokyo Institute of Technology, Dr. Eng.

Assoc. Prof., Ibaraki University, Dr. Eng. 
路沿いの建物群から捉え、その複合として交差点における建物の配 列を検討する。4 章ではこれらを総合し、両者の関係から交差点の 代表的な構成と捉えられる類型注3) を導く。さらに得られた構成類 型を比較検討することから、交差点の空間構成を成立させている枠 組みを構造的に捉え、類型間に共通寸る構成的性格を考察する。以 上により、建築ヴォリュームの配列による交差点の構成類型とその 性格を明らかにし、現代日本の都市空間における街路空間の複合を 形式的な側面から明らかにすることを目的とする。

\section{3 既往の研究}

これまでの交差点を対象とする研究のうち、空間構成に関するも のには、東京の商業地区の交差点の形態的な特徵をイタリアの都市 広場と比較するもの ${ }^{6)}$ 、交差点に面する角地の建物のファサードの 組合せを検討するもの ${ }^{7)}$ などがみられる。前者は交差点の面積やプ ロポーション等の形状を、後者は角地の建物の立面構成を捉えるも のであるが、本研究のように街路に沿う多数の建物の配列を問題に し街路の結節点としての交差点の空間構成を捉えるものではない。 また、交差点の歩行者により把握される現象的側面を検討するもの もみられる。これらは被験者を通した注視や認知、心理的な意識を
検討するもの ${ }^{8,9,10,11)}$ であり、本研究のように空間構成の抽出に主 眼を置くものではない。さらに、交差点の分布による地域的な構造 を捉えるものもみられる。これらは、街路網の数理的な解析手法 ${ }^{12)}$ や、特定の時代や地域の街路網の特徴を検討するもの ${ }^{13,14,15)}$ など、 総じて交差点と道路網の関係を捉えるものであり、本研究のように 交差点自体の空間を問題とするものではない。これらの研究に対し て、本研究は街路に沿う建物の配列から交差点の空間構成を捉え、 複数の街路空間の結節点としての交差点の特徴を明らかにするもの であり、こうした視点から交差点を検討する研究は他にみられない。

\section{2. 交差点の形状と交通高架、河川、地形の組合せ}

ここでは、多様な形状をなす交差点の構成を捉えるため、交差点 の形状と、その立地条件として考えられる地形、河川、交通高架と いった都市の基盤をなす要素との関係を検討する。

都市空間における交差点は直交する十字路だけではなく、三叉路 や五差路、斜めに交わるものなど、多様な形状をなしている。こう した交差点の形状は、交差点一帯の地形や河川、交通高架などの都 市の基盤をな寸要素のあり方と関係していると考えられる。例え
表 1 資料リスト及び分布（東京都心 5 区の幹線道路の交差点）

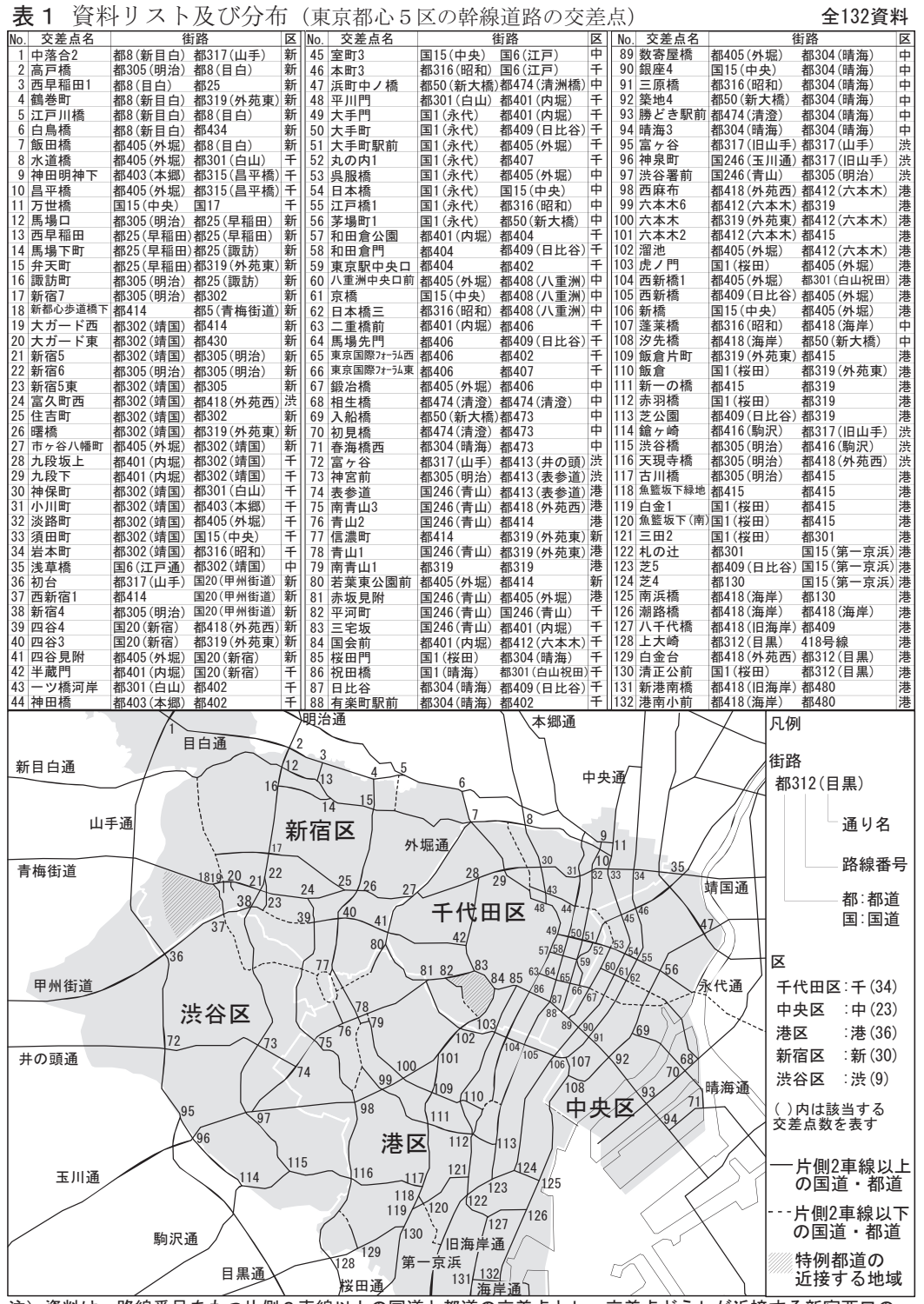

注)资料は、路線番号をもつ片側2車線以上の国道々都道の交差点とし、交差点どうしが近接する新俩西口の 特例都道
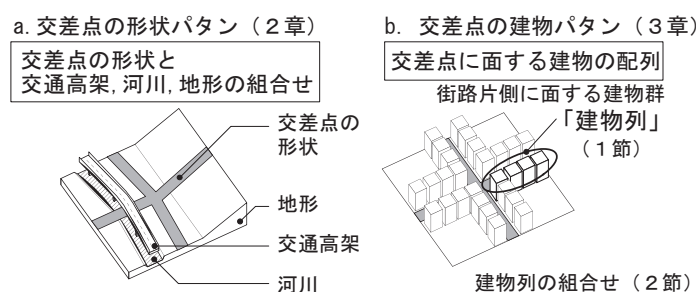

図 1 交差点の空間構成

建物列の組合せ（2 節）

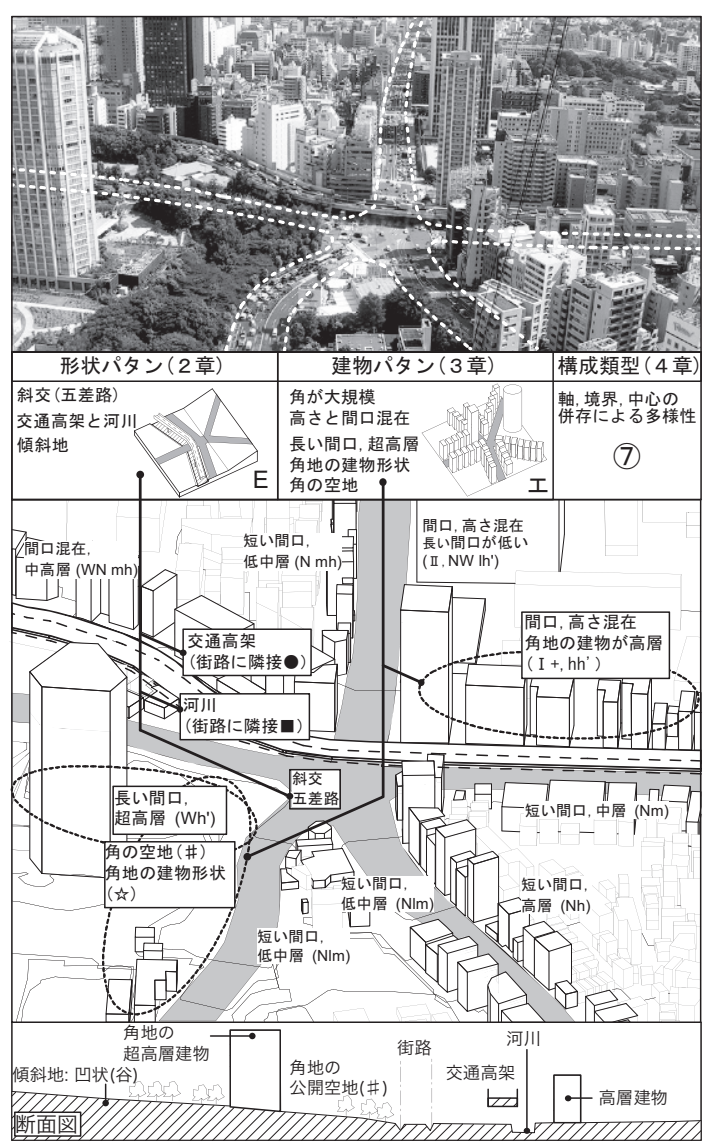

図2 分析例 (No. 112 赤羽橋交差点 港区) 図中の記号は表2〜8に準ずる 
ば分析例（図 2 ）の交差点では、河川と交通高架に沿う街路や谷状 の地形に位置する街路がみられ、これらが交わることにより五差路 をなしている。そこで、まず交差点の形状を三叉路や四叉路といっ た街路数とそれらが直交するか斜交するかといら交わり方から捉え ( 表 2)、さらに、交通高架や河川・堀割・線路などの有無と位置関 係 (表 3 )、交差点一帯が平坦地か、尾根や台地等の凸状あるいは 谷地等の凹状の傾斜地かという地形 (表 4) について検討した。そ の結果、交差点の形状については、四叉路が全資料の約 6 割 $(80 / 132$ 交差点) を占め、三叉路が約 3 割 (40/132)、五差路が約 1 割 (12/132) であった。また街路の交わり方は、直交するものが約 4 割 (50/132) に対して斜交が約 6 割 (82/132) であった。これらの重ね合わせと して交差点の形状を捉えると、いわゆる十字路と呼ばれる直交する 四叉路は資料の約四分の一であり（r iv，34/132）、その他の交差点 では街路数や交わり方に特徴があることが分かった。さらに、交差 点の一帯に交通高架や河川等が位置するもの (86/132)、傾斜地に 位置するもの (59/132) もみられた。

そこで、交差点の街路の交わり方、交通高架及び河川等の有無、 交差点一帯が平坦地か傾斜地かという組合せを検討し、街路数など のその他の属性を下位の傾向として読みとることから、該当数の多 い組合せとして交差点の形状パタンを導いた（表 5 )。形状パタン A は、街路が直交し平坦地にある交差点であり、四叉路のものが多 い(iv, 12/15)。B は同様に街路が直交し、さらに交通高架や河川等 が位置するものである。千代田区と中央区に比較的多く（千または 中 , 25/29)、皇居周辺の堀に隣接する交差点などが該当する。これ ら街路が直交する交差点は平坦地に位置する傾向にあるのに対し、 街路が斜交するものは地形や河川・交通高架等との対応関係がみら れた。C は街路が斜交し傾斜地に位置するものであり、台地などの 凹状、谷地などの凸状の地形ともに該当した。このパタンは新宿区 に比較的多くみられる $(12 / 22)$ 。D は、同様に街路が斜交し交通高 架や河川等が位置する交差点であり、交差点の近傍に位置する河川 等が約半数でみられた（O，13/25）。E は、傾斜地にありかつ交通 高架や河川等をもつものである。これには、交通高架が街路上や街

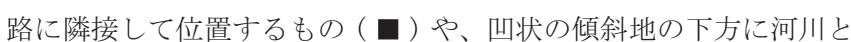
交通高架があり、それらに沿う街路が交差点で交わるといった最も 複雑な組合せ（凹，口かつの）もみられた。これら Eには、五差路 の半数が該当することから (6/12)、複雑な地形と交通高架、河川 等の要素が交差点の形状に影響しているものと考えられる。

以上、交差点の形状と地形、河川、交通高架などの要素との組合 せを検討し、四叉路を主とする平坦地の直交する交差点 (A) から五 差路に特徴的にみられる傾斜地で交通高架や河川がある交差点 $(\mathrm{E})$ まで、特徴的な組合せを捉えることができた。これらに共通する傾 向として、直交する交差点は平地に多くみられ、斜交する交差点で は地形や河川、交通高架との対応関係が認められた。

\section{3. 交差点における建物の配列}

交差点は、前章で検討した街路の形状等により特徴づけられると ともに、様々な建物が交差点を中心に建ち並ぶことにより、立体的 な空間として特徴づけられている。そこで本章では、交差点に面す る建物の配列について検討する。
表 2 交差点の形状（全132交差点）表 3交通高架及び河川等の位置

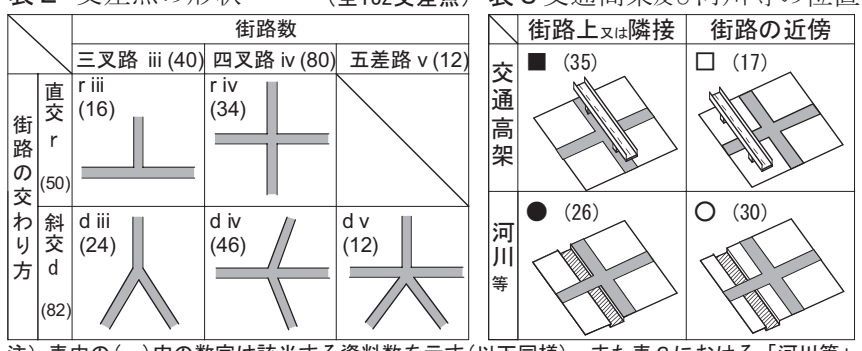

注）表中の（）内の数字は該当する資料数を示す(以下同様)。また表 ろにおける「河川等」 とは河川、堀割、運河などの水部および、 $(\mathbf{\square}, \square, 0,0)$ のいずれかが位置する交差点は86資料であった。

表 4 交差点周辺の地形

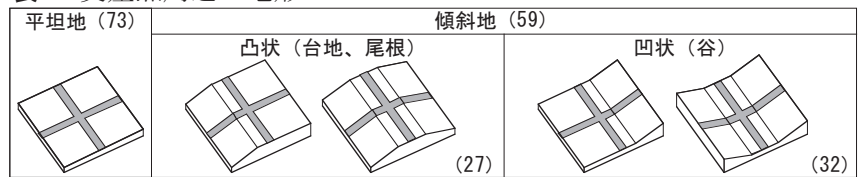

表 5 交差点の形状パタン

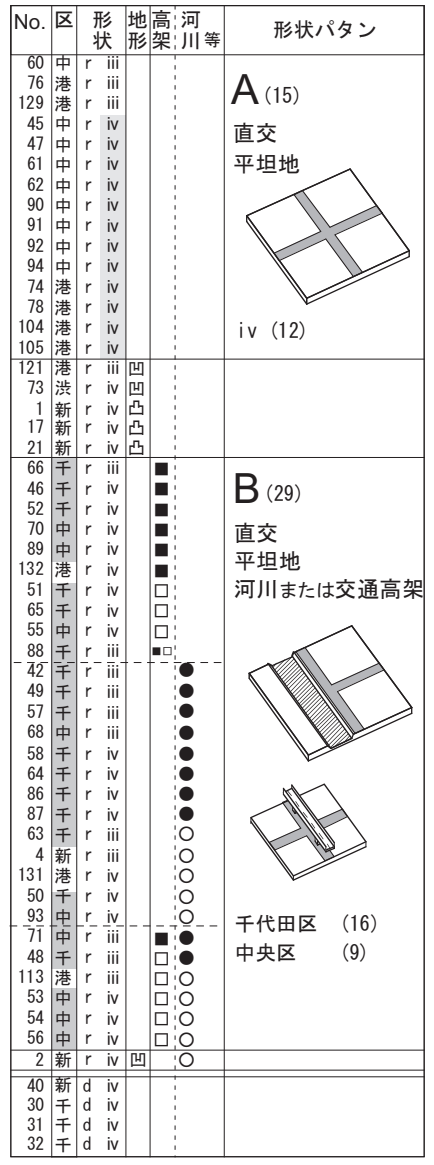

注) 河川等の闌の「線」は地上面の線路を示す。

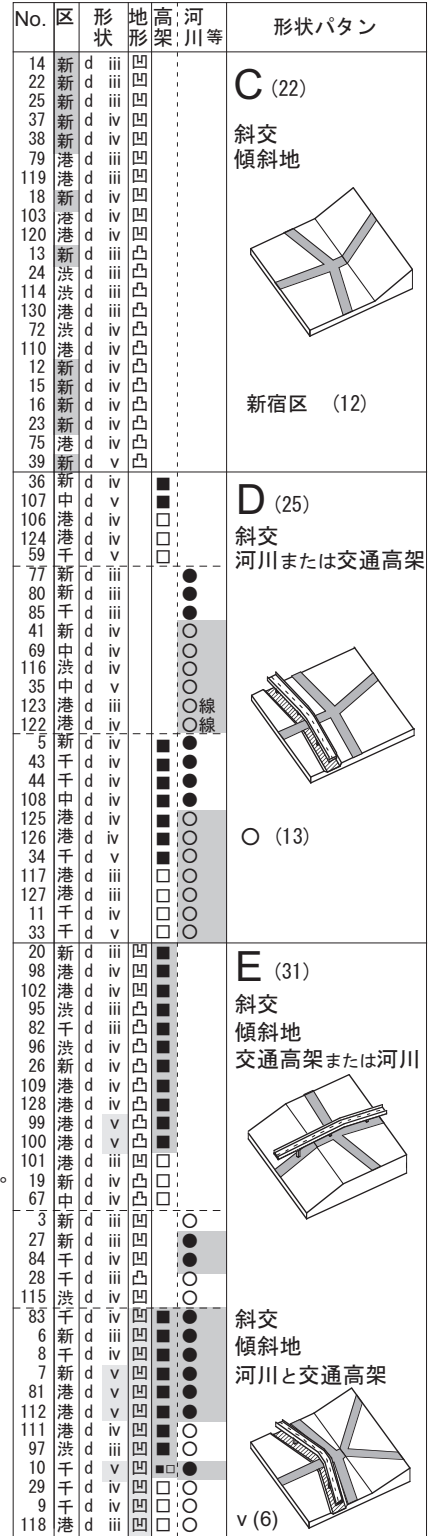

\section{1 街路に面する建物列}

交差点には様々な高さや形態の建物が面している。そこでは、交 差点を中心に街路沿いの建物が多方向に建ち並び、街並みの結節点 として特徴的な場所になっていると考えられる。例えば図 2 の交差 
点では、交差点の一角に超高層建物が公開空地を伴って建ち、さら にその対面に建つ超高層建物も街路沿いの建物から突出しているこ とで交差点を際だたせ、その他の街路沿いの建物も多様な高さと間 口をなして交差点を特徴づけている。こうした多様な建物による交 差点の立体的な特徵を検討するため、交差点一帯の建物を、まず交 差点で交わる街路片側の建物群（以下「建物列」，図 1. b ) を単位 として捉え、その組合せから交差点における建物の配列を検討した。 交差点の街路片側の建物列を捉えたのが表 6 である。ここでは、 建物の立体形状を街路に面寸る建物間口と建物高さから捉えてい る。これら間口と高さともに一様である場合には、おおよそ同形状 の建物によって建物列が構成されていると捉えることができる。そ れに対して、建物の間口や高さが混在している場合には、例えば他 より高い建物が交差点の角にあれば交差点の空間構成に大きく影響 を与えると考えられることから、交差点の角の建物とそれ以外の建 物の違いに着目寸る必要があると思われる。そこで間口一様で高さ 混在の建物列、建物高さと間口の双方が混在する建物列については、 角地の建物が他の街路沿いの建物と比べて高いあるいは間口が長い (+)、低いあるいは間口が短い $(-)$ といった交差点の角に対する規

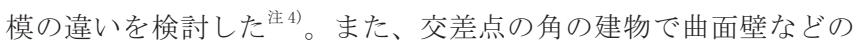
特徵的な形状であるもの、角地に公開空地や公園などの空地が位置 するもの、角以外に空地が位置するもの、といった建物列における 建物形状や空地の配列の特徵についても検討した（表 7 )。

その結果、建物の間口と高さが一様であるものでは、長い間口で 高層・超高層などの高層系の建物による列が多くみられ（長高， 182 列)、ついで短い間口で中層・中高層などの中層系のものも比 較的多かった（短中, 113 列)。また数は多くないが、短い間口で 低層・低中層の低層系の建物（短低）や、同じく低層で長い間口の 建物による列（長低）は、本研究で捉えている建物の形状として小 規模なものであり、交差点において他の建物列と組み合わさる場合 に特徴をなすものと考えられる。次に建物間口が混在し高さが一様 なものでは、高層系の建物が多く該当した（混高, 153 列）。また 建物間口が一様で高さが混在するものでは、角地とそれ以外の建物 の違いについても検討したところ、短い間口の建物からなり交差点 の角が低い列（短混一）が比較的多かった。またこれとは逆に、長 い間口の建物で角地の建物が高い列もみられた（長混+)。さらに、 建物の高さと間口がともに混在するものは、間口の長い建物が高い 場合 (混混 I) が多く、こうした大規模な建物が交差点の角に位置 するもの（混混 I+) と角以外にあるもの（混混 I-）ともにみられた。 また建物がなく公園などの空地が街路片側の全体にあるものもみら れた（表 6 付図，V)。また曲面壁などの角地の建物形状の特徵は資 料の約 3 割に (表 7 , 方:43/132 交差点)、公開空地や公園などの 空地が角地にあるものは半数に該当した（＃:66/132）。

以上、交差点の街路の片側における建物列について検討し、建物 の間口と高さの関係から特徵的な建物の組合せを見いだした。

\section{2 建物列の組合せによる交差点の建物の配列}

前節で検討した建物列を交差点ごとに組み合わせ、交差点全体に おける建物の配列を検討寸る。これらの建物列において、長い間口 や高層の建物からなる列（長高，混高，長混+）、角地の建物が大規 模である列（混混 I+）は、比較的大規模な建物による列であり交差 点の空間構成に及ぼす影響が大きいと考えられる。またこうした建
表 6 街路片側における建物列 全981列（建物列910, 空地71）

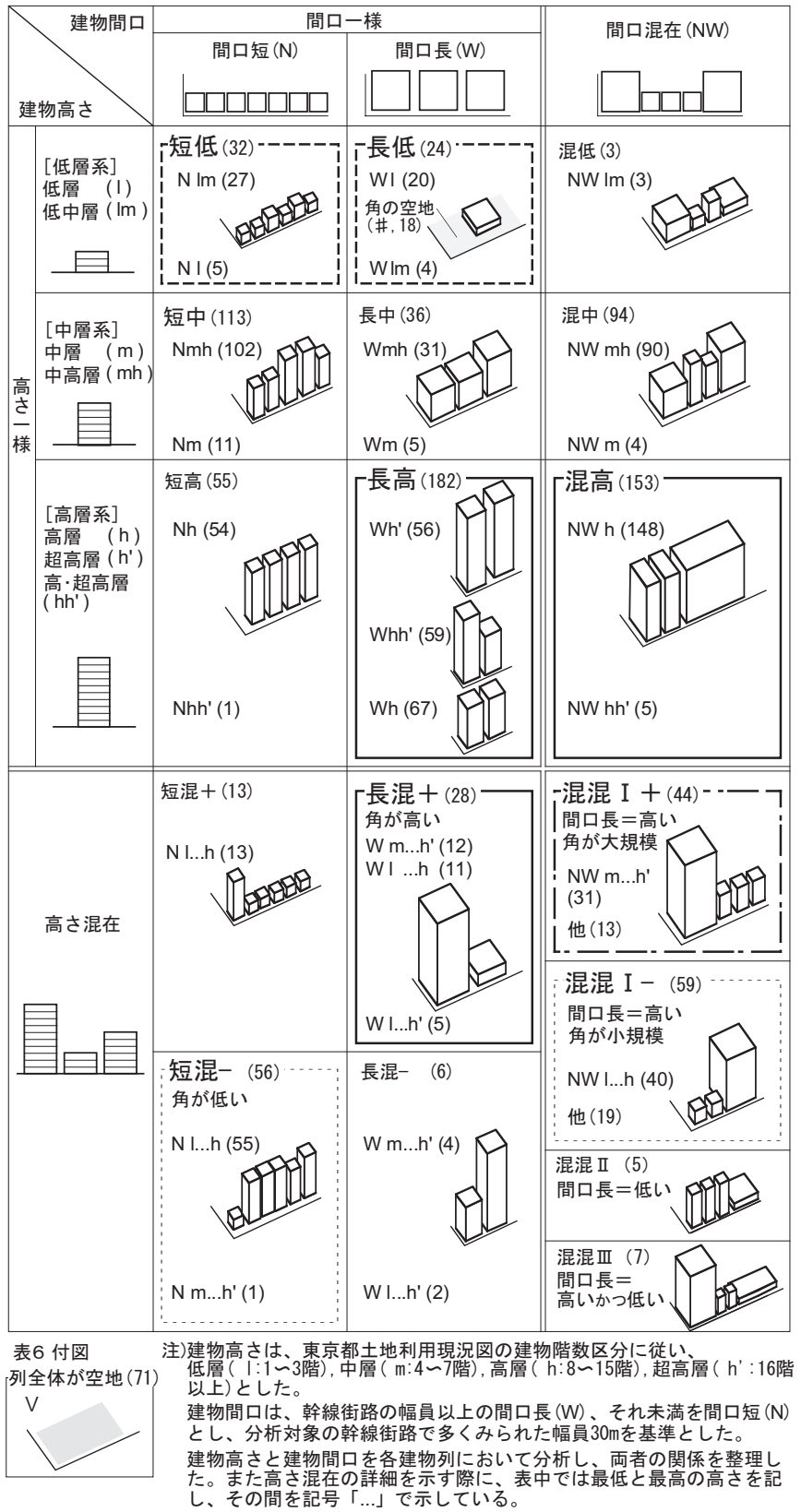

表7 角地の建物及び空地の特徴

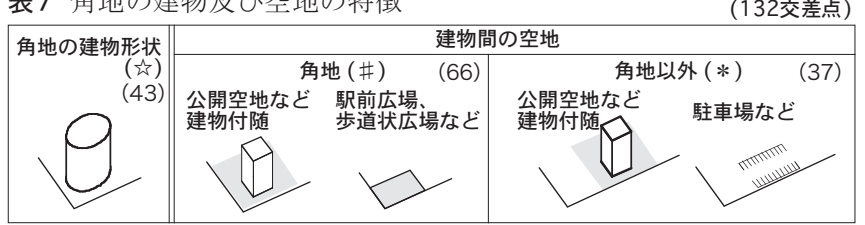

表8 同種の建物列の配列の特徵

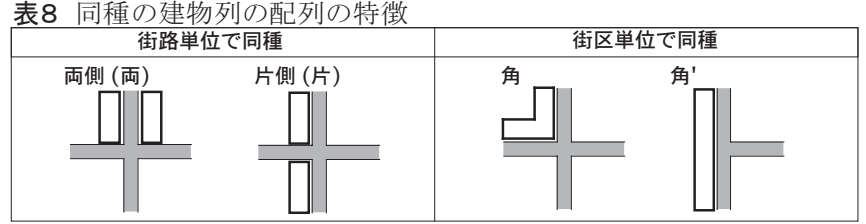

物列とは対照的に、短い間口で低層の列（短低）や同じく低層で長 い間口の建物による列（長低）、建物がなく全体が空地である列 (V) も、他の列と組み合わさることで交差点の街路の中で小規模な建物 列による特徴のある部分をなしていると考えられる。そこでこれら 
表 9 建物列の組合せによる交差点の建物パタン

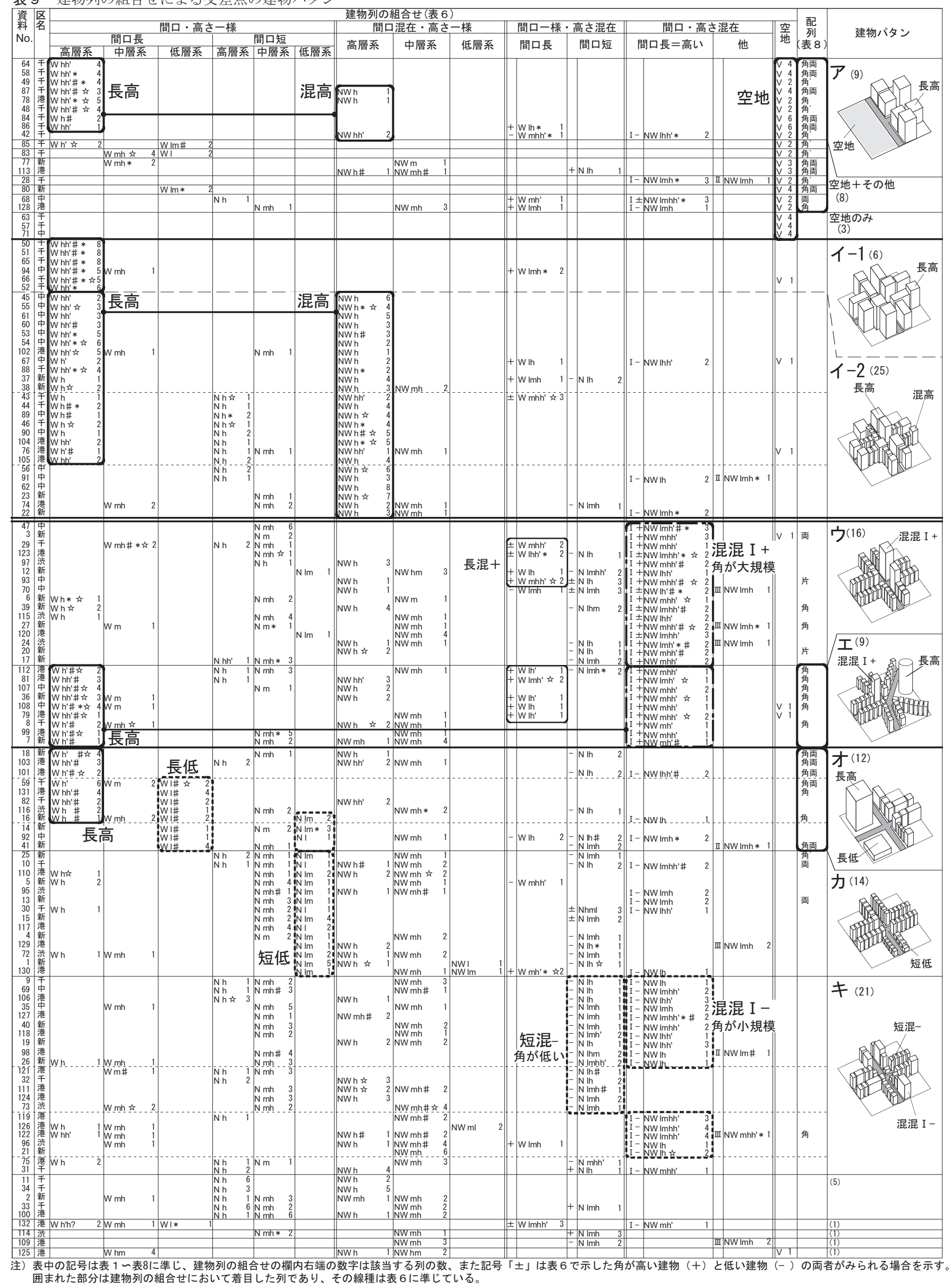


の建物列 (表 6 , 囲み) に着目し、さらにそれらが街路の両側や片側、 交差点の角で連続するなどの配列の特徴（表８）をあわせて検討す ることから、建物列の組合せによる交差点の建物の配列（以下、建 物パタン) を導いた（表 9)。

建物パタンアは、空地である列 $(\mathrm{V})$ が複数あり、それ以外は高層 や超高層の長い間口の建物を含む列（長高，混高）からなるもので ある。これらは交差点が大規模な公園などに面するものであり、千 代田区の皇居周辺などに多くみられる。イは、アと同様の長い間口 で高層系の建物を含む列が、交差点の大半を占めるものである。こ のうちイー 1 は、長い間口の建物からなる列が大半のもので (長高)、 公開空地などを角地や街路の奧に伴うものが多い（，*）。イ-2 は、 これに加えて建物間口が混在するもので（混高）、中央区の銀座周 辺などにみられる建物高さが高層で揃いながら間口が多様な建物列 を含むものである。これらアとイは建物の高さが高層または超高層 で一様に揃うものである。

これに対してウは、他より大規模な建物が角地に位置する列（混 混 I+）をもつ交差点である。この建物は超高層である場合が多く (h')、曲面壁などをもつ特徵的な建物形状であるものもみられる （ぬ）。エはこうした建物列に加えて、公開空地などを伴う超高層 かつ長い間口の建物列（長高, Whh'\#）をもつもので、これらが 交差点の角で連続するものが多い（角）。再開発地区などの一画が 交差点に面するものにみられ、多種の建物列が交差点から多方向に 展開するものである。これらウとエは、他より大規模な建物が交差 点に面することにより特徴づけられる交差点である。

以上の建物パタンは高層や長い間口といった大規模な建物の列が 交差点の主要な部分を構成するのに対して、オは、長い間口で高層 や超高層の建物の列 (長高) があるが、それが交差点の一部である 場合や、長い間口で低層の建物の列（長低）がある場合、その両者 をもつ場合など、交差点において建物の規模の違いがあらわれてい るものである。新宿西口の超高層街区や、長い間口の低層建物をも つ大学キャンパスなど、周囲の中層程度の建物と対比的な建物を含 む列が面することにより、交差点が周辺の地区の境界となっている ものと言える。カは、短い間口で低層の建物の列（短低）をもつも のである。その他の建物列は中高層を主とすることから、戸建住宅 等の小規模な建物による列が他の中高層の建物列に対して相対的に 特徴をなすものと言える。キは、交差点に面する角地のみが小規模 な建物である（短混一, 混混 I-)。これらオ，力，キは、低層や短 い間口などの小規模な建物が交差点に面することにより特徵づけら れるものである。

以上、交差点に面する建物の配列について検討した結果、高層ま たは超高層の高さが一様な建物によるもの（ア，イ）、他より大 規模な建物が面することで交差点の角が特徴づけられるもの（ウ， エ）、小規模な建物が交差点に面することで特徴づけられるもの （オ，カ，キ）として捉えることができた。

\section{4. 交差点の空間構成}

ここまで交差点の空間構成を、交差点の形状と地形·交通高架・河 川等の組合せと、交差点を立体的に特徴づけている建物の配列から 位置づけ、それぞれ 2 章と 3 章において検討した。本章ではこれらの 結果をもとに、 2 章で導いた交差点の形状パタンと 3 章で導いた交差
点の建物パタンを重ねて検討することで交差点の構成類型を導く。 ここまでの結果を併せて検討し、交差点の形状パタン（２章）と、 交差点の建物パタン（３章）を両軸とするマトリクスを作成し、全 資料を付置したものが表 10 である。両軸の組合せのうち、該当数 の多いものを構成類型とし、各章のパタンにおいて下位の属性とし た内容についてもあわせて、その特徴を以下に述べる。

交差点の構成類型(1)は、平坦地の直交する交差点に、高層または 超高層の建物の列が面する交差点である。該当する資料の大半が四 叉路（iv）で、建物間口の長短が混在しているものであり (イ-2)、 中央区や港区に多くみられる。この類型の一例として銀座 4 丁目交 差点（No.90）では、角地の建物が曲面などの特徵的な形状（飞）で あることが、高さが一様な建物の集合のなかで特徵をなしていると 考えられる。(2)は、(1) と同様に平坦地の直交寸る交差点であるが、 堀割等が隣接し (の)、その向こうに空地、他方に長い間口の高層・ 超高層の建物が建ち並ぶものである。日比谷交差点（No. 87） など千 代田区の皇居外苑や公園に面するものが該当し、堀割等に接する境 界が一方向に開放されている交差点である。(3)、交差点の一帯に 交通高架を伴い（口または口）街路が直交するものであり、(1)と同様 に高層系の建物の列が面する交差点である。この類型には空地を伴 うものが多く（＃または＊)、交通高架が街路に重なる箇所が公園に なっているものや、高架下にある堀割と街路が交わる箇所にかつて からある橋詰広場が残存しているものなど、交通高架があることで 大規模な建物の間に空地が位置する交差点である。数寄屋橋交差点 (No. 89) はこの類型に該当し上記の特徴を備えている。

以上の(1) (3)は、平坦地の直交する街路における高層系の建物の 集合による交差点である。これに対して以下の類型は、斜交する街 路において、多様な規模の建物が混在する交差点である。(4)は、尾 根などの凸状の地形にある斜交する交差点において、短い間口の低 層建物からなる列とその他の中高層の建物列が組み合わさるもの である。この類型に該当する飯倉交差点（No.110）では、小規模建 物が建ち並ぶ坂道を登ると交差点に曲面壁をもつ特徴的な高層建 物（认）が建っており、街路と地形、建物の配列が合わさって特徴 的な交差点が形成されている。小規模建物からなる建物列には、近 年の拡幅により幹線街路となったものが比較的多く注5)、新規の幹 線街路に従来からある小規模な建物が残存しているものと考えられ る。(5)は、交通高架または河川等が位置する斜交する交差点におい て、中高層建物が建ち並ぶなかで角地のみが低層建物である構成で ある。交通高架や河川に沿う街路と他の街路が斜めに交わり、角地 が変形敷地であるものが特徵的にみられ、そうした敷地における小 規模な建物が交差点に面するものである。芝 4 丁目交差点（No.124） など、港区の湾岸部の運河や交通高架に沿う交差点にみられる。

(6)，(7)，(8は、(4)でみられた地形の起伏と(5)でみられた交通高架・ 河川等の双方がみられる斜交する交差点である。このうち(6)、交 差点の角の超高層建物が他の建物より突出して建つものである。三 叉路であるものが多く（iii）、交差点の近傍にある河川へと下る谷状 の地形 ( ○かっ凹) や、曲面状の建物形状（认）により、角地の超 高層建物が交差点のランドマークとして強調されているものと言え る。渋谷区や新宿区に多くみられ、渋谷川に向から傾斜地にある渋 谷署前交差点（No.97）などが該当する。７）は、こうした突出した高 さの建物とともに、主に五差路 $(\mathrm{v})$ の交差点の一角を公開空地など 
（＃）を伴う超高層の大規模建物が占め、その他の建物列や、街路 に隣接する交通高架（口）とともに交差点を中心に多様な構築物が 位置する構成である。得られた類型のなかで最も複雑な特徽をもつ ものと言え、六本木六丁目交差点（No. 99）など、地形に起伏のある 大規模な開発地区が交差点に面するものにみられる。(8)、地形の 起伏と交通高架がみられ、中高層の建物の集合のなかで交差点の角 に低層建物が建つものである。(5) と共通する特徴をもちながら、さ らに起伏のある地形と街路に隣接する交通高架を伴う傾向がみられ

( 口)、西麻布交差点 (No.98) などが該当する。

以上の類型は交差点の形状（形状パタン）と建物の配列（建物パ タン）との間に対応関係があり類型として抽出されたものである。 これに対して、交差点が周辺の地区の境界となるような、規模が異 なる建物が面する建物パタンオでは、特定の形状パタンとの対応は 認められなかったが、街路が斜交するあり方（形状パタン C, D, E)
に分布する傾向がみられた。すなわち、建物パタンオに該当する超 高層の大規模建物からなる新宿西口地区や、長い間口の低層建物か らなる大学キャンパスなどが、斜交する交差点を地区の境界として いる傾向を示寸ものである。これらの資料は、他の類型より大枠の 水準で交差点の建物と形状の間に関係がみられるもので、その他の 類型に準ずる類型99と捉えられる。

以上の交差点の構成類型をまとめると、大枠としては、直交する街 路に高層で一様な建物が面する交差点 ( (1)一(3) )、地形や交通高架、 河川などの複雑な立地条件をともない斜交する街路に多様な規模の 建物が面寸る交差点 ( (4)一(9)※) という、2つのあり方として捉える ことができる。両者について、東京都心 5 区における地域的な分布を みると、前者は千代田区と中央区、後者は港区、新宿区、渋谷区に分 布するという比較的明確な傾向が認められ、街路と立地条件および建 物の地域的なあり方を示すものとして、本研究で対象とした地域に潜

表10 交差点の構成類型

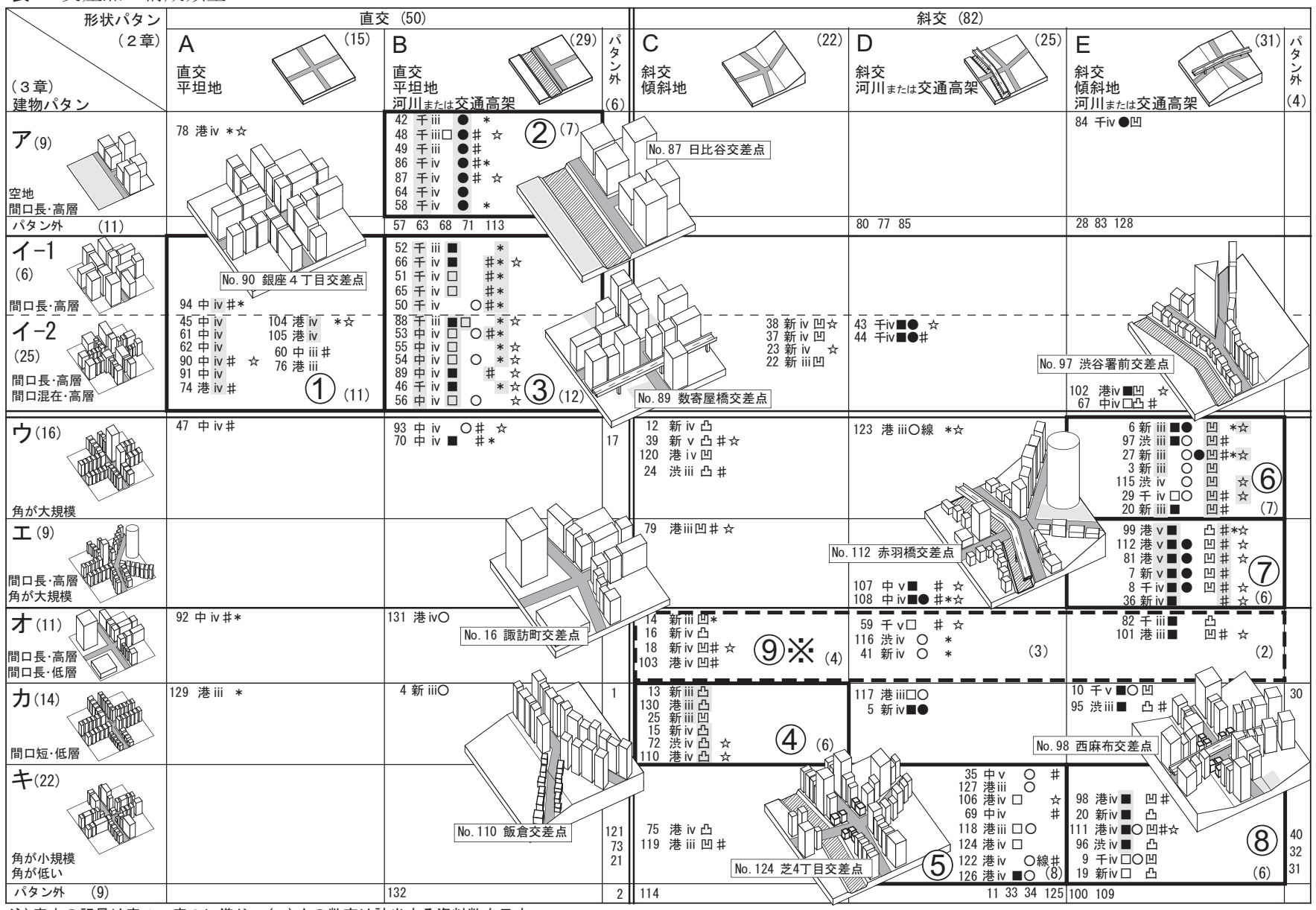

注) 表中の記号は表 1 〜表 8に準じ、（）内の数字は該当する資料数を示す。

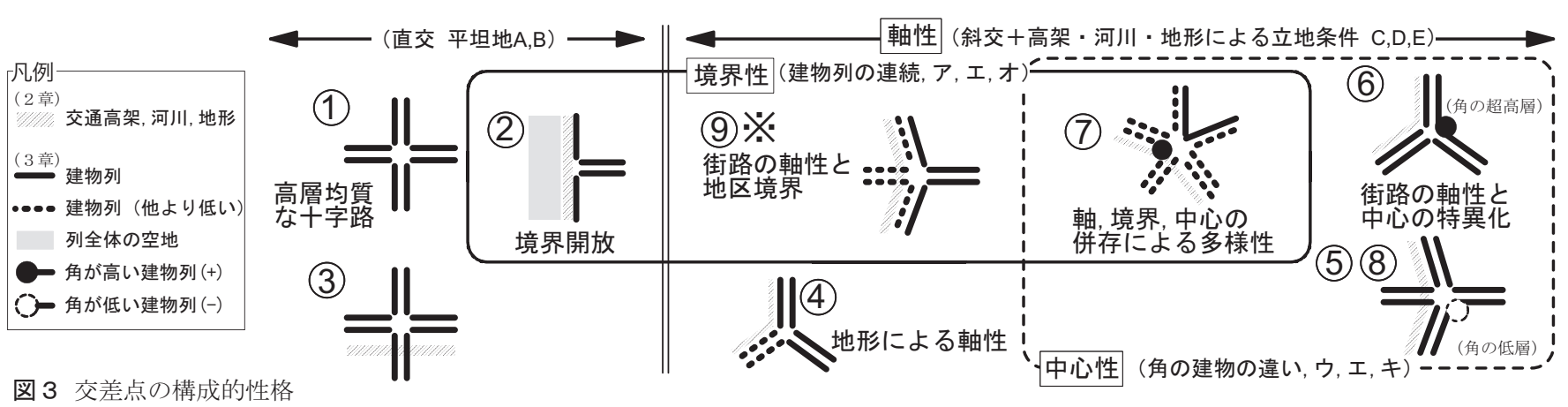


在していた傾向であると考えられる。その上で、交差点に特有の空間 構成上の特徴を考察するため、得られた構成類型を、共通する構成 的な性格にもとづいて整理したのが図 3 である。主に四叉路の直交 する街路に高層かつ大規模な建物が面する(1)，(3)、建物規模が一 様に高層であり、街路も均質であることから、「高層均質な十字路」 と言える。(2)は、堀割等に接する境界が空地に面し、都市の大規模 な空地による「境界開放」として特徴づけれられる。これらに対し て、交通高架、河川、地形などの立地条件を伴って斜交する交差点 の特徽のひとつとして、(4)は、地形に沿って斜交し低層建物が建ち 並ぶことで「地形による軸性」が形成されている交差点である。(5)， （6)，8は、角地の建物が他より大規模であったり（６）、反対に角 地の建物が低層であること（ (5)，(8)）により、交差点の中心が他と 比べて特異な部分となっているもので「街路の軸性と中心の特異化」 と言える構成である。さらに、いずれかの立地条件により斜交する 交差点において、規模が異なる建物が地区の境界をなす(9)※は「街 路の軸性と地区境界」と言える交差点である。これらに対して(7)は、 河川や地形がみられる三叉路や五差路の交差点において、角地の建 物が他より大規模であるとともに、交差点の一角の超高層の建物が 複数の街路に面して地区の境界をなすもので、「軸、境界、中心の 併存による多様性」と言える構成である。また以上の交差点の構成 的性格は、斜交する街路と交通高架、河川、地形などの立地条件に より形成される交差点の「軸性」、角地の建物の規模により交差点 の中心が他と比較して特異な部分となる「中心性」、同じ建物列が 連続し交差点に面して建物の規模が異なる地区の境界が形成される |境界性」という 3 つの枠組みにより捉えることができた。

\section{5. 結}

本研究では交差点の空間構成について、まず交差点で交わる街路 の形状と、立地条件である地形や河川、交通高架の組合せにより、 交差点の形状パタンを導き、四叉路を主とする直交する交差点、五 差路にみられる傾斜地で交通高架や河川を伴う交差点などの特徵的 な組合せとともに、それらに共通する傾向として、直交する交差点 は平坦地に多く、斜交する街路は地形や河川、交通高架との対応関 係がみられることを明らかにした。

次に、交差点の空間を立体的に特徴づけている建物の集合を、街 路片側の建物の列を単位として捉えることから交差点の建物パタン を導き、高層で一様な建物の列に対して、交差点の角に大規模な建 物が位置するもの、小規模な建物により交差点の角や列が特徵づけ られるものという建物の規模の組合せによる特徴を明らかにした。

さらに交差点の形状パタンと建物パタンを併せて検討することか ら構成類型を導き、共通する構成的な性格にもとづいてそれらを考 察した。その結果、交差点の空間構成は、街路が直交し高層で一様 な建物が面するものとして「高層均質な十字路」と「境界開放」、 また複雑な立地条件を伴って街路が斜交し多様な規模の建物が面す るものとして「地形による軸性」、街路の軸性と中心の特異化」「街 路の軸性と地区境界」「軸、境界、中心の併存による多様性」とい う 6 の構成的性格として捉えられることを明らかにした。また、こ うした街路空間の複合による空間構成は、街路の「軸性」、交差点 の角の建物による「中心性」、建物の規模の違いによる「境界性」 の 3 つの枠組みとして捉えることができることを明らかにした。
注

注 1 ) 江戸初期の表通りの角地には城郭風の大規模な町屋が建てられ、景観上特 徵的な場所となっていた (参考文献 1 )。

注 2 ) 本研究では交差点を中心とする $200 \mathrm{~m}$ の範囲を分析 対象としている。全資料において、交差点の中心から 街路に隣接する河川や掘割の対面までの最大距離（約 $170 \mathrm{~m}$, No. 41）を含む範囲 $200 \mathrm{~m}$ を分析対象とした。なお分 析では、交差点の形状については各区の管内道路図また け都市計两施設図、建物形状と高さについては土地利用期 平成 18 年度版) をもとに、全資料を現地調査して確認した。

注 3 )「類型」とは「(1)一定種類に属する多数の個別形式を包摂する形式。ある 特徴を共通にしている一群の事物について、その特徴を抽き出して作った 型。」(参考文献 5 ) であり、本研究では分析を通して資料の集中する代表的 な構成として、単に「(1)種類によって分けること。（参考文献５）を意味す る「分類」と区別して用いている。

注 4 ) 高さ一様・間口混在の場合には、幹線街路では建物が密実に建ち並ぶこと が一般的であり、高さが一様であれば建物の壁面が揃い、間口の長短が街路 から明確に認識されないことから、角地とその他の違いを検討していない。

注 5 ) 類型(4)に該当する 6 資料のうち、4 資料 (No. 13 早稲田通りと新目白通りの 間, No. 25 台町坂, No. 72 井の頭通り, No. 130 目黒通り) は、近年 10 年以 内に拡幅された幹線街路を含むものであった。

\section{参考文献}

1 ) 陣内秀信 : 東京の空間人類学, 筑摩書房, 1985

2 ) 安森亮雄, 坂本一成, 寺内美紀子 : 建築ヴォリュームに囲まれた都市の空地 の構成形式-現代日本の都市空間における空地の構成形式に関する研究-, 日 本建築学会計画系論文集第 568 号, pp. 69 - 76, 2003.6

3 ) 安森亮雄, 坂本一成, 横山志穂, 寺内美紀子 : 建築ヴォリュームの配列によ る駅前広場の空間構成 東京都 23 区 JR 線におけるケーススタディー - 現代 日本の都市空間における空地の構成形式に関寸る研究 (2) - , 日本建築学会 計画系論文集第 622 号, pp. 83-90,2007. 12

4 ) 安森亮雄, 坂本一成, 寺内美紀子：東京都 23 区 JR 駅における駅前広場の集 合形式 -現代日本の都市空間における空地の構成形式に関寸る研究 (3) - , 日本建築学会計画系論文集第 632 号, pp. 2099 - 2105, 2008. 10

5 ) 広辞苑, 岩波書店, 1998

6 ) 木下智康, 西成典久, 齋藤潮 : 都市広場としての潜在性に着目した交差点の空 間構成に関寸る基礎的研究 - 中世イタリアの都市広場の空間的特徵との比較 を通じて -, 日本都市計画学会都市計画論文集 No. 43-3, pp. 97 - 102, 2007. 10

7 ) 小池秋彦, 田口陽子, 那須聖, 八木幸二 : 都市中心部の角地建築群のファ サードにより形成される交差点空間, 日本建築学会大会学術講演梗概集 (東 北) F-1 分冊, pp. 805 - 806, 2000.9

8 ) 知花弘吉 : 交差点付近における車イス利用者と健常者の注視特性, 日本建築 学会計画系論文集第 510 号, pp. 155 - 160, 1998.8

9 ) 青野文晃, 松本直司：十字型交差点の角地における壁面後退街路の空間形状 意識 - 街路の空間形状意識に関寸る研究 (その 5) - , 日本建築学会大会学術 講演梗概集 (九州) E-1 分冊, pp. 791—792, 1998.9

10）足立啓, 赤木徹也：異種条件別交差点シミュレーション画像に対する注視特 性一痴呆性老人と精神薄弱者の視覚情報探索行動に関する研究 第 3 報, 日本 建築学会計画系論文集第 513 号, pp. 111 - 117, 1998.11

11）角舘政英, 小林茂雄, 海藤哲治 : 地域性と横道認知を考慮した交差点の光 環境整備の提案-富山市八尾町を対象として, 日本建築学会環境系論文集第 610 号, pp. $19-25,2006.12$

12) 腰塚武志: 道路網と交差点, 日本都市計画学会一般研究論文 都市計画第 103 号, pp. $36-41,1978.9$

13）油浅耕三 : 正保城絵図による城下町の道路の交差形態と交差点密度に関する 考察, 日本都市計画学会一般研究論文 都市計画第 167 号, pp. 89-99, 1991.2

14）篠原一男, 苅谷武郎, 高坂秀一, 武田光史, 浦田義久, 友常仁二：城下町の 形態研究 I -その 3 ・道の性格について一, 日本建築学会大会学術講演梗概 集 $($ 東北 $)$, pp. 1573 - 1574, 1973. 10

15）小嶋勝衛, 荻住真, 根上彰生 : 銀座繁華地区の空間構成に関する研究 その 2 交差点による地区構造把握 一繁華地区の空間構成に関する研究 その $12-$, 日本建築学会大会学術講演梗概集 (関東), pp. 1381 - 1382, 1979.9 